\title{
EVIDENCE FOR PERFORMANCES OF REPUBLICAN COMEDY IN FOURTH-CENTURY ROME*
}

In a recent study Katherine Dunbabin has assembled and brilliantly elucidated a group of Roman monuments dating from the second to the fourth century and all featuring actors of tragedy and/or comedy standing near a mysterious instrument consisting of a base upon which is mounted a fairly large circular disk - the whole apparently situated on a stage at the margin(s) of the playing area. From the upper rim of this disk there are five stalks crowned by smaller disks - and on some of the monuments these smaller disks are consecutively numbered with the Greek letters $A B \Gamma \Delta E$, i.e. from one to five. In two instances, the instrument is handled by a youth, one of whom observes the actors while holding what seems to be a book scroll. ${ }^{1}$

Carefully examining iconography and contexts, Dunbabin makes a strong case for identifying the said disk as an instrument that during Late Antiquity was used on Roman stages to signal which act was playing. On this reading the monuments in question (a bronze disk, three marble reliefs and a mosaic representing two such objects) that all hail from Rome or the western part of the empire, illustrate procedures that seem easiest to understand if five-act versions of comedy and tragedy were still part of what the Roman stage at this relative late period had on offer.

In the 'continuing discussion of what was put on in Roman theatres and of how long traditional drama may be thought to have continued' this is, as observed by J.R. Green, 'important evidence of a direct kind'. ${ }^{2}$ The masks, cothurni and socci of the actors shown on these monuments confirm that we are dealing with tragedy and comedy but, sadly, the items in question do not enable us to determine which were the five-act dramas that would have been performed on these occasions. However, on this latter issue there is, if I am not mistaken, relevant evidence to be gleaned from a series of passages in the commentary on Terence by Aelius Donatus (fl. A.D. 353). ${ }^{3}$ Of these passages the first and most controversial (ad Ter. An. 716.1), with which the present article will begin, not only seems to imply that Terence's Andria was a play Donatus expected his readers to have seen, but further that they would have seen its five acts performed with a woman playing one of its female roles.

\footnotetext{
* I am indebted to the CQ's editor and anonymous referee for several inspiring suggestions

${ }^{1}$ K.M.D. Dunbabin, 'A theatrical device on the Late Roman stage: the relief of Flavius Valerianus', JRA 19 (2006), 191-212.

2 J.R. Green, 'Theatre production: 1996-2006', Lustrum 50 (2008), 7-302; 367-91, at 295-6.

${ }^{3}$ On Donatus, see the survey by P.L. Schmidt, $\S 527$ (Aelius Donatus) in R. Herzog (ed.), Restauration und Erneuerung. Die lateinische Literatur von 284 bis 374 n. Chr. Handbuch der lateinischen Literatur, vol. 5 (= HdbA VIII.5) (Munich, 1989); on discussions of his links to actual performance, the surveys by J.R. Green, 'Theatre production: 1971-1986', Lustrum 31 (1989), 7-95; 273-8 and 'Theatre production: 1987-1995', Lustrum 37 (1995), 7-302; 309-18 are along with Green (n. 2) the place to start.
} 
Returning finally to the issue of performance, I shall examine some references in Donatus (ad Ter. Eun. praef. I.5; ad Ter. Ad. praef. I.4) which seem to throw new light on why his contemporaries might have needed an instrument to keep track of which act was playing when they were watching such classical repertoire.

\section{A FEMALE MYSIS IN ANDRIA?}

As for the female actors, the passage in question (Donat. ad Ter. An. 716.1, quoted in extenso below) is unusual in so far as Donatus does not otherwise seem to refer so directly to the theatre of his own day. To understand the nature of this - as it seems - uniquely direct reference it is therefore crucial to acknowledge what is a basic and probably traditional element in his hermeneutics. ${ }^{4}$ As a rule (not to say on principle) Donatus is consistent in drawing inferences about the kind of stage the reader should imagine from the words of the dramatist or the actors themselves. For Donatus - as indeed for Aristotle ${ }^{5}$ - the real theatre with its sometimes impressive but always ephemeral opsis clearly had no permanent authority. What remained and mattered were the indications of the script.

When offering comments about the behaviour and movements of Terence's actors, such as hoc dixit non ut Simo, sed ut spectator audiat ('this he said so that the spectator, but not Simo hears it'), ${ }^{6}$ constitit tamen aliquantum intuens spectatores, dum secum loquitur ('for a while he stands still, regarding the spectators as he talks to himself'), ${ }^{7}$ or hic sermo sic prodit, ut post scaenam incohatus esse noscatur ('from the layout of this speech it emerges that it was begun offstage'), ${ }^{8}$ Donatus nowhere claims to be basing his approach on actual performance. For him, the chief authority is not what one might have seen on stage, but the script itself. Again and again he appeals to what Terence wrote or his actors say, on this basis suggesting what one can reasonably infer about the implied setting and the implied movements of the actors. ${ }^{9}$ What Donatus offers, in short, reflects $a$ well-established reading strategy aimed at making such scripts cohere by referring to their implied scenography. For such purposes Donatus and his readers clearly knew a fairly wide range of basic scenographic possibilities and conventions; all would know - and his schoolboy readers be reminded - how to imagine a scene, inferring what the script implied and on that basis supplying the imaginary props and settings, gestures and movements needed to appreciate the dramatic qualities of the script.

Is the entrance left or right and which are the gestures and movements implied by the script? Who says what? And is it addressed to a fellow actor or is it an

${ }^{4}$ R. Jakobi, Die Kunst der Exegese im Terenzkommentar des Donat (Berlin and New York, 1996), 8-10 identifies Donatus' strong links with the traditions of Hellenistic and Imperial literary commentary.

${ }^{5}$ Arist. Poet. 6.28; for a similar stance, see Hor. Ars P. 180-2.

${ }^{6}$ Donat. ad Ter. An. 498 (here and in what follows I quote the edition of P. Wessner, Aeli Donati quod fertur commentum Terenti I-III [Leipzig, 1902-8]); for further parallels, see Donat. ad Eun. 431.1 de ipso loquitur, non audiente; ad Eun. 394.2 tertia persona uenit in scaenam, sed separatim loquitur et secum; and E. Csapo and W.J. Slater, The Context of Ancient Drama (Ann Arbor, 1994), 29, nos. 59a-f.

${ }^{7}$ Donat. ad Ter. Eun. 232.1.

${ }^{8}$ Donat. ad Ter. Eun. 391.1.

9 Jakobi (n. 4), 13 quotes some twenty inferences of the type 'ex ipsius uerbis'. 
aside? ${ }^{10}$ These are the kind of questions to which his commentary (or rather, what is left of it) ${ }^{11}$ again and again reverts. In his approach Donatus is at points antiquarian, not only in his prefaces, but sometimes also in individual comments, telling the occasional stage anecdote (the drunken Ambivius Turpio) or explaining origins (why did the stage have an altar?), ${ }^{12}$ but when discussing acting it is in the present context noteworthy that he tends to operate in 'performance present', suggesting what is happening at a given point on stage (be it virtual or otherwise). Most entries deal with entrances and exits, asides and gestures; but comments can also be found on more intricate procedures, such as those employed when handling stage interiors. The original may of course have had more of this kind, but even from what has survived, it seems clear that such comments by no means drew only upon the text itself (as has sometimes been asserted). Instead they combine knowledge (be it direct or otherwise) about stage conventions with the words of the script. ${ }^{13}$ In the said comment, on a scene (III.4) in the Adelphoe, the girl next door is with child - and suddenly her labour begins, her painful cries and anguished prayer to Juno Lucina being clearly heard from within her mother's house. Scandal is imminent, the burning issue being the identity of the father. To sort out what happens, a family friend enters - at which point Donatus reminds his reader that there are two kinds of stage interior: one in which actors simply leave the 'stage' (proscaenium), the illusion being that they would transact their remaining business in a fictive offstage 'interior'. But in cases like the present, Donatus claims, they would stay on the proscaenium, the 'interior' (intus) being situated 'behind' what he calls $\tau$ ò $\pi \iota$ a áóv ('the convincing thing') - a fair guess being that he is referring to the use of an illusionistic flat representing a house facade, from behind which the audience would have heard the girl's cries. ${ }^{14}$

Knowledge of this and similar stage conventions (there seems to be no means of ascertaining their origin and date) may of course have been transmitted by the tradition on which Donatus drew. In other cases his inferences may simply be based upon analogy. It has, however, often been observed that Donatus, when commenting on such aspects betrays a remarkably keen eye for the dramatic qualities of Terence, a circumstance that, quite understandably, has made scholars wonder whether this is simply because Donatus was an imaginative reader - or, alternatively, whether his commentary, be it directly or otherwise, is influenced by the actual experience of performance.

${ }^{10}$ Left or right: see Donat. ad Ter. An. 751, cited below; who speaks: ad Eun. 786.2; asides: see n. 6 and ad An. 759, cited below.

${ }^{11}$ For the complicated transmission of what appear to be excerpts of Donatus' lost original, see Wessner (n. 6), xliv-xlix and Jakobi (n. 4), 5-6.

${ }^{12}$ The drunken Ambivius Turpio: Donat. ad Ter. Phorm. 315.2; altar: ad An. 726.1.

${ }^{13}$ Jakobi (n. 4), 13 perhaps oversimplifies when claiming that Donatus' 'bühnentechnische Scholien ... sind evident aus dem Text selbst gezogen'; as illustrated by the comment quoted in n. 14 below (which Jakobi does not discuss), at least sometimes Donatus combines the words of the script with very specific knowledge of the workings of the stage.

${ }^{14}$ Donat. ad Ter. Ad. 511.2: meminisse debemus, quod dixit (sc. Hegio) 'duc me intro ad

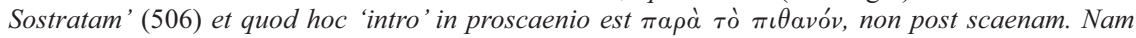
aliud significat 'eamus intro', ubi dicitur (An. 981) 'intus despondebitur, intus transigetur, si quid est quod restat'; illud enim interius agitur extra omne proscaenium. There seem to be no means for dating the introduction of flats of this kind. Nor is it clear how far their use was uniform. Donatus (or his abbreviator) has nothing on the procedure in his comment on the very similar scene at An. 473.4, there claiming that the voice is heard from 'behind the stage' (post scaenam). 
This is where a brief passage in his commentary on the Andria becomes relevant because, when discussing the prominent role of the slave girl Mysis in this comedy, Donatus suddenly departs from his usual procedure and instead acknowledges that 'now' (nunc) - as opposed to what happened in the 'old days' (apud ueteres) - a woman would have played this role.

An isolated comment, this intriguing evidence has frequently been either dismissed $^{15}$ or overlooked. ${ }^{16}$ When acknowledged at all, its wider implications for understanding Donatus' approach have rarely been pursued, ${ }^{17}$ the most notable exception being J.W. Basore who in his 1908 Baltimore dissertation argued that this passage reflects what in Donatus' day could actually be seen on stage. ${ }^{18}$

Recently, Rainer Jakobi, in his invaluable discussion of Donatus' hermeneutics, has come to a very different result, concluding that, if Donatus is referring to performance at all, ${ }^{19}$ it is to something happening in other dramatic genres - but certainly not in comedy. In support of this negative conclusion Jakobi offers no direct evidence. Briskly dismissing the very possibility of such performances, he instead outlines various options, suggesting that Donatus is perhaps referring to a 'performance tradition not using masks' (Aufführungspraxis ohne Masken) ${ }^{20}$ or to what 'women' actors (Frauen) did in mimes (which basically would amount to much the same). ${ }^{21}$

${ }^{15}$ While claiming that there were no fourth-century performances of Terence, W. Madyka, De Donato histrionum praeceptore (Wrocław, 1953), 57 (despite his book's title) dismisses Donatus' report, arguing that Donatus' performance-related comments were directed at future rhetors. The one need not exclude the other.

${ }^{16}$ No reference in e.g. M. Schanz and C. Hosius, Geschichte der römischen Literatur I (Munich, 1927), 108; I. Opelt, 'Das Drama der Kaiserzeit', in E. Lefèvre (ed.), Das römische Drama (Darmstadt, 1978), 427-57; or Csapo and Slater (n. 6).

${ }^{17}$ A number of scholars quote, but do not discuss the passage: among them L. Friedländer, Darstellungen aus der Sittengeschichte Roms in der Zeit von Augustus bis zum Ausgang der Antonine (Leipzig, 1922 ${ }^{10}$ ), 2.119 n. 4; A. Müller, 'Das Bühnenwesen in der Zeit von Constantin d. Gr. bis Justinian', Neue Jahrbücher f. d. kl. Altertum, Geschichte und deutsche Literatur 23 (1909), 36-55, at 40; G. Duckworth, The Nature of Roman Comedy (Princeton, 1952), 76; H. Leppin, Histrionen. Untersuchungen zur sozialen Stellung von Bühnenkünstlern im Westen des römischen Reiches zur Zeit der Republik und des Prinzipats (Bonn, 1992), 43; R. Webb, 'Female entertainers in late antiquity', in P. Easterling and E. Hall (edd.), Greek and Roman Actors. Aspects of an Ancient Profession (Cambridge, 2002), 282 and C.W. Marshall, The Stagecraft and Performance of Roman Comedy (Cambridge, 2006), 94 n. 38.

18 J.W. Basore, The Scholia on Hypokrisis in the Commentary of Donatus (Baltimore, 1908), 10 (seen at <http://www.archive.org/stream/scholiaonhypokr02basogoog\#page/n18/mode/1up >); without quoting the passage in question, M. Thomadaki, 'La mise en scène du théâtre de Terence dans les commentaires de Donat', Dionisio 59 (1989), 365-72, at 372 speculates along similar lines.

${ }^{19}$ Jakobi (n. 4), 12 considers it unclear whether the passage refers to 'wirkliche Dramen- oder gar Terenzaufführungen'.

${ }^{20}$ From Donatus' repeated references to the uultus, i.e. 'facial expressions', of the actors Jakobi (n. 4), 12 n. 34 infers that he was imagining or referring to performances featuring actors not wearing masks. But actors wearing masks were also perceived as having expressive uultus: Cic. Div. 1.80 in Aesopo ... tantum ardorem uultuum; similarly, Sen. Ep. 11.7. Marshall (n. 17), 127 is excellent on the myriad ways in which masks are perceived in actual performance; when referring to the actors' uultus Donatus may therefore well be imagining (or referring to) what the actors' masks would be perceived to express.

${ }^{21}$ Jakobi (n. 4), 12: 'Näher liegt die Annahme, dass Donat den Mimus im Sinn hat (in dem tatsächlich Frauen auftraten), mit seinem knappen ut nunc uidemus also lediglich sagen will: "wie wir jetzt Frauen auf der Bühne agieren sehen <sc. im Mimus>", 
The Andria performed without masks and by actors of mime, male and female? The notion is intriguing, but Jakobi does not pursue it. And on closer inspection it is in my view doubtful that there is anything to pursue:

... et uide non minimas partes in hac comoedia Mysidi attribui, hoc est personae femineae, siue haec personatis uiris agitur, ut apud ueteres, siue per mulierem, ut nunc uidemus.

... and note that in this comedy a by no means insignificant part is entrusted to Mysis, that is a to a female character (personae femineae), be it that she (haec) is played by men wearing masks, as happened in the old days, or - as we now see it - by a woman. ${ }^{22}$

As I read it, this comment does not in any way suggest a scenario with women actors performing in mimes. Donatus first acknowledges that much is entrusted to this 'female character' and then moves on to recall how 'she' in the old times had been played by 'men wearing masks', but nowadays by a 'woman'. Far from mentioning any women - let alone mimes - his reference is unmistakably to 'a woman' performing as Mysis in Terence's Andria. Donatus, moreover, says nothing about this female actor wearing no mask, but only that she is a she. Had he wanted to stress a difference between 'men wearing masks' and 'women not wearing masks' (as was the case with the mimes), he could easily have done so by writing for instance mimas ('[female] mime actors') rather than mulierem ('a woman'). As it is, all his text brings across is a difference of gender.

Crucially, such performances were what Donatus and his readers might now see (ut nunc uidemus) - and for all that this is an isolated reference, there is no justification for a priori dismissal. At this point of time, such performance is, to be sure, commonly considered rare or even implausible, but rather than on positive evidence, this latter assumption is based upon a set of seemingly convergent ex silentio inferences. When coming across what strongly looks like evidence to the contrary, detailed scrutiny therefore seems in order. All the more so, since it is easy to see why Donatus here diverges briefly from his usual focus on the poet's own words.

The scene, in which Mysis holds a central part, is a bravura piece of comedy within comedy, with poor Mysis desperately struggling to keep track of the role Davus expects her to play. As we shall see presently, Donatus repeatedly comments on its comic potential, but it is when, in his usual style, he introduces this scene by commenting on its place in the plot $^{23}$ that he (briefly to elaborate) adds a gloss on the prominence of Mysis, then goes on to explain how her role would have been played then as opposed to now.

In his commentary - or rather, in the numerous excerpts from his lost original ${ }^{24}$ - such 'how-it-was-in-the-old-days' glosses (apud ueteres or apud antiquos) are so common that their well-established place in the original seems beyond reasonable doubt. Parallels confirm that such comments were part of a scholar's traditional armoury. Covering a wide range of subjects such as grammar, spelling, changes in

${ }^{22}$ Donat. ad Ter. An. 716.1; for parallels to personatis uiris agitur, see Donat. ad Ter. Ad. praef. 1.6 personati agebant; Eun. praef. 1.6 agentibus ... personatis and De com. 6.3 personati ... egisse.

${ }^{23}$ Donat. ad Ter. An. 716.1: Haec scaena administrationem doli habet, quo fit ut deterreatur Chremes filiam suam Pamphilo dare. et uide non minimas partes in hac comoedia Mysidi attribui...

${ }^{24}$ For the transmission of Donatus, see n. 11. 
vocabulary and of course in dramaturgy, the information offered by such glosses ranges from the exceptional to the trivial, much of it being duplicated by other 'guardians of language' (to use the expression of Robert Kaster) ${ }^{25}$ Here, however, where the amount of rival evidence is patchy in the extreme, the gloss on Mysis' varied life on ancient stages by pure accident offers something truly precious, since, in an offhand manner, it acknowledges not only that but also in what form at least one of Terence's comedies in Donatus' own day still had a stage life of its own.

As with many such surprise survivals, the passage in question raises more questions than it answers. When and why the role of Mysis (and probably others of her dramatic sisters) was taken over by female actors is for instance not clear. For Varro, Quintilian and Juvenal, comedians were male. ${ }^{26}$ But at some point the everpopular mimes may well have led to a change. Here women traditionally played star roles - and a transfer of such talent to one of the revered classics is not a procedure that a priori seems implausible. Whatever the date and circumstances of this transfer, it is moreover clear that it proved sufficiently memorable to have become common knowledge and standard procedure. Donatus' ut nunc uidemus is in the present rather than a praeteritum evoking a one-off memorable occasion. True, there is the possibility that the reference was inherited from a predecessor, but such mindless compilation is - as Jakobi rightly stresses - not in Donatus' style. ${ }^{27}$ This, moreover, is a factual gloss, so even allowing for the idea that it might be inherited, it would still leave us with a valuable reference to a (from all we know) post-second-century and, at the latest, mid-fourth-century reform in the manner of performing classical comedy.

On the evidence available there is, however, no reason to doubt that the comment is Donatus' own. And with his school being in Rome, where he was revered as the grammaticus and orator urbis Romae, ${ }^{28}$ it may reasonably be inferred that his reference is to performances of Terence in the imperial capital.

But, one might ask, is Donatus referring to an excerpt or a solo, or to a performance of the whole play? With no positive evidence either way, a brief look at the context might provide some clues. Here it seems notable that while Mysis makes her first entrance during the Andria's first act (I.4-5) and then in III.1 and IV.2-5, her role throughout is one of brisk dialogue and close-knit interaction, her final appearance part of a comedy within the comedy that only comes off when played opposite fellow actors. What Donatus has in mind is therefore unlikely to be a solo recital featuring a famous actress. There is simply not enough material in this role to give such a performance substance, let alone entertainment value. Instead, I would suggest, the set-up to imagine may well be the kind of five-act performance illustrated by the second- to fourth-century monuments identified by Katherine Dunbabin. These monuments are all urban in context or inspiration and

${ }^{25}$ For further apud ueteres glosses in Donatus, see Donat. ad Ter. An. 490.5 et apud ueteres puer puellus puera puella; similarly, An. 398.5; 508.2; 521.3; Ad. 87.3; 168; 181.1; 423; 559.2; Phor. prol. $1.2 ; 287.1 ; 363.5 ; 371.3 ; 415.1$. Other glosses report customs apud antiquos (Hec. 39.4: hoc abhorret a nostra consuetudine, uerumtamen apud antiquos gladiatores in theatro spectabantur) or quote the expressions or spellings of the 'ancients': Eun. 10.1, 'thesaurum' Latini ueteres secundum Graecos sine N littera proferebant; similarly, An. 481.2; 492.2.

${ }^{26}$ Varro, Ling. 10.2.27; Quint. Inst. 11.3 .91 (Greek [male] comedians overdoing it when playing women); Juv. 3.95; the only evidence for comoedae seems the passage in Donatus: Leppin (n. 17), 43.

${ }^{27}$ Jakobi (n. 4), 13 n. 36.

${ }^{28}$ This is how Donatus is described in the manuscripts. 
the performances clearly all public, thereby providing a suggestive foil against which to appreciate what the orator urbis Romae at line 716 has to say not only about Mysis being played by a woman, but, in subsequent comments (e.g. at $722,741,745,746,751$ and $759^{29}$ ), about the dramatic qualities of the passage in the Andria that prompted his initial reference to the way it was performed in his own day:

haec scaena actuosa est, magis enim in gestu quam in oratione est constituta.

This scene is all acting, being based more upon gesture than words.

(ad An. 722.1)

non interrogantis est, sed mirantis et non intellegentis, ut appareat eum non oculis prius quam corporis offensu sensisse puerum iacentem.

This is not the words of someone asking, but of a person being astonished and unable to understand, thus making it clear that he notices the baby lying before him not by seeing but by stumbling bodily over it.

(ad An. 741.2)

haec uerba sunt uenientis de foro.

He speaks like someone coming from the forum (i.e. entering through the gate reserved for those coming from the forum).

(ad An. 745.1)

hoc propter spectatores.

This is for the audience's benefit.

(ad An. 746.2)

bene 'ad dexteram': sinistra enim uenit Chremes.

'To the right' is good - Chremes enters from the left.

(ad An. 751.1)

hic uersus clare dicitur, sequens, ne senex audiat, presse.

This line is spoken out loud, the following at low volume so that the old man does not hear it.

(ad An. 759)

These are, of course, all inferences that might solely and ultimately be based upon Terence's own implicit stage directions. In practice - and probably in principle this was clearly the approach that Donatus preferred. But given his remarkable grasp of their comic and sheer dramatic potential, which was admired by readers from Erasmus to Lessing, the evidence that the scenes with the quick-witted Davus and groggy Mysis were part of the theatrical repertoire of Donatus' own day seems to add a new, more theatrical dimension to the genesis of the single most influential line-for-line commentary in the history of Western drama. ${ }^{30}$ 


\section{WHICH ACT IS NOW PLAYING ?}

A stage apparatus serving as an act counter: the reading suggested by Katherine Dunbabin seems to imply that audiences of Late Antiquity seeing a performance of classical five-act drama would have needed - or at least appreciated - some kind of indication as to how far into the plot they now were. But is there evidence to support this view? In my view, two passages in Donatus look relevant. In both passages he readily acknowledges that in Terence the five-act division is difficult to establish - but he nowhere seems to doubt that it is there at all. Far from it, only 'men of little learning' (parum doctis) and the 'unlearned spectator' (inconditi spectatoris) had difficulty in understanding such niceties, these divisions having been cleverly made less clear-cut by 'the learned men of old' (doctis ueteribus). ${ }^{31}$ Terence and his fellow 'Latin comedy writers' (Latini comici) had done so because they did not want to let the act divisions split up the flow of the action, fearing that the 'unenthusiastic' (fastidiosus) spectator would take 'some intermission in the continuous flow of events' (distincta alicubi continuatione succedentium rerum) as a signal to leave the theatre before the final curtain, thus becoming 'disrespectful of the remainder of the comedy' (reliquiae comoediae ... contemptor).

Donatus' reasoning is basically a case of having one's cake and eating it - but what matters here is that it underlines the prestige involved in knowing what was by no means obvious. Rome was a society which put a premium on learning. For the appreciation of classical drama, the five-act divisions were clearly felt to matter. But to interrupt the flow of action was considered a drawback. Perhaps the act counter was a discreet attempt to have it both ways, signalling when an act was at an end without having to bring performances of the tragic and comic classics to an undesirable standstill.

Danish National Art Library

PATRICK KRAGELUND

pkr@kunstbib.dk

${ }^{31}$ The two central passages on the deliberate hiding of the five-act divisions are Donat. ad Ter. Eun. praef. I.5: actus sane implicatiores sunt in ea et qui non facile a parum doctis distingui possint, ideo quia tenendi spectatoris causa uult poeta noster omnes quinque actus uelut unum fieri, ne respiret quodammodo atque, distincta alicubi continuatione succedentium rerum, ante aulaea sublata fastidiosus spectator exsurgat; and Donat. ad Ter. Ad. praef. I.4: actus ... quos etsi retinendi causa inconditi spectatoris minime distinguunt Latini comici metuentes scilicet, ne quis fastidiosus finito actu uelut admonitus abeundi reliquae comoediae fiat contemptor et surgat, tamen a doctis ueteribus discreti atque disiuncti sunt... 